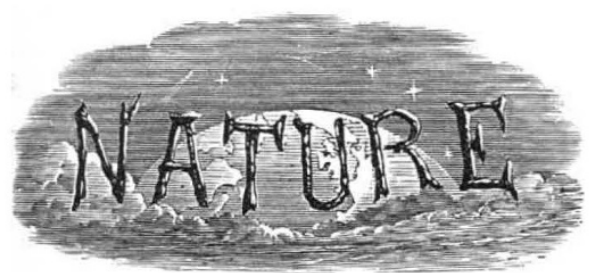

SATURDAY, FEBRUARY 7, 1925.
The Future of the British Patent Office

The Imperial College of Tropical A Reminiscences of Great Naturalists. By Prof. J Arthur Thomson .

Modern Views on Cytology. By Prof. J. Brontë Gatenby

General Chemistry .

Our Bookshelf

Letters to the Editor:

The Origin of Sponge-Spicules.-Prof. Arthur Dendy, F.R.S.

On the Excitation of Spark Spectra.- Sven Werner Rainfall Correlations in Trinidad.-W. R. Dunlop Astrophysics without Mathematics. - Prof. Herbert Dingle ; Prof. E. A. Milne

The Structure of the so-called Ultraviolet Bands of Water Vapour.-G. H. Dieke . . .

Hafnium Oxide in Tungsten Filaments.-J. A. M. van Liempt

Citrus Fruit and Scurvy.-Prof. W. A. Osborne . Australopithecus africanus: The Man-Ape of South Africa. By Prof. Raymond A. Dart Biographical Byways. By Sir Arthur Schuster, F.R.S.-6. S. P. Langley .

Obituary :-

Dr. J. M. Ellis McTaggart. By Prof. G. Dawes Hicks

Mr. C. H. Wordingham. By A. R.

Mr. George Abbott .

Current Topics and Events

Our Astronomical Column

Research Items

Scientific Work of the Fishery Board for Scotland.

By Prof. W. C. McIntosh, F.R.S.

Science and the Instrument Industry

The Botanic Garden, Copenhagen

University and Educational Intelligence.

Early Science at Oxford

Societies and Academies .

Official Publications Received .

Diary of Societies.

Editorial and Publishing Offices:

MACMILLAN \& CO., LTD.

ST. MARTIN'S STREET, LONDON, W.C. 2

Editorial communications should be addressed to the Editor.

Advertisements and business letters to the Publishers.

Telephone Number: GERRARD 8830.

Telegraphic Address: PHUSIS, WESTRAND, LONDON. NO. 2884 , VOL. 1 I 5 ]

\section{The Future of the British Patent Office.}

卫HE British patent system is a matter which concerns all workers in applied science, for it represents an attempt-faulty and incomplete, but still an attempt-to secure for such workers the credit for their achievements, together with a share of the material advantages arising from these. Hence any event which seriously affects the future of the patent system is one to which the scientific world should give careful consideration, and such an event is just beginning to appear on the horizon. Lest it should take shape before its implications have been seriously canvassed, it may be well to direct attention to some of its aspects. There is a rule which requires Government servants to submit to superannuation at an age when many men are still capable of their best work, and since the rule appears to be inexorably applied, the retirement of the present Comptroller of the Patent Office and the appointment of his successor must be regarded as inevitable in the not very distant future. It is perhaps a little early to discuss this question, but not too early; for when the first official intimation of such a change is given, the selection of the successor may be actually, if not formally, a fait accompli.

That a scientific office should have a scientific man at its head is a principle which seems obvious but needs to be constantly reasserted, because the administrative officials who influence such appointments are not always sympathetic towards the claims of science. In fact, a lack of sympathy in that direction is sometimes manifested to a degree which exposes it to strong criticism, as in the proceedings of committees $\mathrm{A}, \mathrm{B}$, and $\mathrm{C}$ of the National Whitley Council, and in the general tendency to regard the man of science as a mere adviser who is himself incapable of administrative work. Such an attitude is the more unjustifiable from the fact that a scientific training is necessarily always additional to some degree of education in the humanities, whereas a literary scholar may be quite ignorant of science; so that the former type of upbringing is the more likely to produce the breadth of outlook which is necessary in handling men and affairs.

Taking the British Patent Office as an example, let us examine the qualifications which are necessary in the man who is to direct its labours. The duties of the Comptroller fall under three heads as follows :

(r) $\mathrm{He}$ is the senior Hearing Officer for disputes as to patents, trade marks, and designs. He has to adjudicate in "oppositions" brought by interested parties against the grant of particular patents, as well as in cases where examiner and applicant fail to agree in regard to the official requirements put forward by 
the former. Thus the Comptroller is a court of first instance for certain classes of patent litigation; and although he delegates this duty in a proportion of cases to subordinate Hearing Officers drawn from the examining staff, in the remaining cases he acts personally. For the adequate discharge of this function, the importance of which is obvious, the Comptroller should have legal knowledge, experience of patent practice, and such a wide training in scientific matters as to be able readily to appreciate, in the structure and functioning of electrical, mechanical, and chemical systems, those details and subtleties around which patent litigation so frequently turns. Should he lack the latter qualification, the new Comptroller would in many instances be thrown on the mercy of his advisers from the examining staff, and so would relinquish both his dignity and, in the case of disagreement between examiner and applicant, his judicial neutrality.

(2) He will command the staff of the Patent Office, in addition to those of the Trade Marks and Designs Branches. The essential work of the Patent Office is carried on by the examining staff, comprising (according to the last Annual Report) more than 250 men having the necessary scientific qualifications, while the routine incidental to their labours necessitates a supplementary staff comprising roughly an equal number of clerical workers. It would be unreasonable to subordinate the examining staff, in the years that lie ahead, to the control of a man who is not qualified, by a scientific training similar to theirs, to understand the outlook and the mentality with which such training is associated. It must be remembered that fundamental changes in the relative importance of the scientific and clerical sections of the staff have followed the changes introduced into the patent system by the Act of 1907 .

(3) The new Comptroller will be called upon to advise the government of the day with regard to the improvement and extension of the patent system, which has certain unsatisfactory features, the chief being its incompleteness. It is incomplete because the official search is arbitrarily limited to British specifications, because it is imperfectly co-ordinated with other patent systems throughout the British Empire, and because adequate use is not made, for the benefit of national and industrial technology, of the special knowledge acquired by the examining staff (though the latter criticism does not apply to the War period, when many of the staff were drafted to the Ministry of Munitions). In the reconstruction of the Patent Acts the new Comptroller will play a pivotal part, and it is desirable, therefore, that he should have first-hand knowledge of the way in which the present system has worked in practice. Equally must he be a man of broad views and open mind, gifted with that sense of proportion and that fair for actualities which characterise the thinking of the quantitative and experimental sciences.

Where, it may be asked, is it possible to find a candidate possessing the necessary legal knowledge, scientific training, experience of patent practice, and largeness of outlook? Three classes of men immediately suggest themselves : (I) The patent bar, (2) the patent agents, and (3) the examining staff of the Patent Office itself. There are difficulties to be encountered in each case. As regards the third group, it is not the general practice of the Treasury to put at the head of a department a man promoted from within it, and we do not know in what circumstances exceptions to this rule are considered feasible. If the Comptrollership should be filled from within the Board of Trade, technical and not purely administrative attainments should decide the appointment. As regards the other two classes, the difficulty is that successful patent barristers and successful patent agents are able to make incomes many times greater than the salary attached to the Comptrollership. The dignity of the office might perhaps combine with the opportunity of public service which it offers to attract a man of the necessary calibre, but there is a fairer and wiser way to meet the difficulty in question. That way is, to raise the salary of the post to a level commensurate with the importance of the latter.

The public interest would suffer if the new Comptroller were to be a man whose lack of the requisite qualifications was only compensated by the possession of influential friends. Particularly would it be undesirable to fill such a post by promotion from the "administrative" or clerical grades of the Civil Service. There is a right place in the scheme of things for the bureaucratic mentality, but that place is not at the head of the Patent Office. While it is true that the business of the State could not be carried on without the meticulous observance of precedent, the mastery of complicated routine, the punctilio of official etiquette which are the special merits of the clerical civil servant, it is equally true that such gifts are not adequate to enlist the confidence of subordinates and of the public on behalf of the chief of a technical office already over-ripe for innovation and development.

Whatever decision may be taken when the time comes, it is earnestly to be hoped that no candidate will even be considered who does not combine with experience of patent practice a thorough training in physical science. It should be an absolutely inviolable principle that an essentially scientific staff should have a man of science at its head. 